\title{
Interleukin-1 Receptor Antagonist Ameliorates Experimental Anti-Glomerular Basement Membrane Antibody-associated Glomerulonephritis
}

\author{
Winson W. Tang, Lili Feng, James L. Vannice, * and Curtis B. Wilson \\ Department of Immunology, The Scripps Research Institute, La Jolla, California 92037; and * Synergen, Inc., Boulder, Colorado 80301
}

\begin{abstract}
The contribution of IL-1 to leukocyte infiltration in anti-glomerular basement membrane (GBM) antibody (Ab) glomerulonephritis (GN) was examined by the administration of a specific IL-1 receptor antagonist (IL-1ra). Lewis rats received anti-GBM Ab or normal rabbit serum and were treated with either $0.9 \%$ saline or $6 \mathrm{mg}$ IL-1ra over a 24-h time period. Plasma IL-1ra concentration was $2,659 \pm 51 \mathrm{ng} / \mathrm{ml} 4 \mathrm{~h}$ after anti-GBM Ab and IL-1 ra administration. PMN and monocyte/macrophage infiltration declined $39 \%(9.8 \pm 1.9$ to 6.0 \pm 1.5 PMN/glomerulus, $P<0.001)$ and $29 \%(4.9 \pm 0.8$ to $3.5 \pm 0.8$ ED-1 cells /glomerulus, $P=0.002$ ) with IL-1 ra treatment at $4 \mathrm{~h}$, respectively. Similarly, the number of glomerular cells staining for lymphocyte function-associated molecule-1 $\beta$ (CD18) declined $39 \%$ from $16.7 \pm 1.9$ to $10.7 \pm 1.6$ cells/glomerulus at $4 \mathrm{~h}(P=0.0001)$. This was associated with a decrease in glomerular intracellular adhesion molecule-1 expression. The mean glomerular intracellular adhesion molecule-1 score in anti-GBM Ab GN rats treated with IL-1ra was less than that of rats administered anti-GBM $A b$ and $0.9 \%$ saline at 4(2.0 \pm 0.2 vs $2.5 \pm 0.2, P<0.05)$ and $24(2.5 \pm 0.1$ vs 3.1 $\pm 0.2, P$ $=0.0001) \mathrm{h}$. These immunopathologic changes correlated with a $50 \%$ reduction in proteinuria from $147 \pm 34$ to $75 \pm 25 \mathrm{mg} / \mathrm{d}(P$ $<0.002)$. Treatment with IL-1 ra did not affect the steady state mRNA expression of either IL-1 $\beta$ or TNF $\alpha$. An increase in the IL-1ra dose to $30 \mathrm{mg}$ given within the initial $4 \mathrm{~h}$ provided no additional benefit. The decline in PMN and monocyte/macrophage infiltration of the glomerulus at $4 \mathrm{~h}$ was similar to that found in the initial study. Furthermore, the protective benefit of IL-1 ra was abrogated by doubling the dose of the anti-GBM Ab GN, despite administering high dose IL-1ra (30 mg). In these studies, detectable IL-1ra was found in the serum of untreated anti-GBM Ab GN controls. These data suggest a positive yet limited role for IL-1ra in the therapeutic intervention of antiGBM Ab GN. (J. Clin. Invest. 1994. 93:273-279.) Key words: intracellular adhesion molecule-1 - lymphocyte function-associated molecule-1 $\bullet$ neutrophil $\bullet$ macrophage $\bullet$ proteinuria
\end{abstract}

\section{Introduction}

IL-1 is a polypeptide cytokine produced by inflammatory and intrinsic glomerular cells that presumably contributes to the

Address correspondence to Curtis B. Wilson, M.D., Department of Immunology (IMM-5), The Scripps Research Institute, 10666 North Torrey Pines Road, La Jolla, CA 92037.

Received for publication 14 January 1993 and in revised form 26 July 1993.

J. Clin. Invest.

(c) The American Society for Clinical Investigation, Inc. 0021-9738/94/01/0273/07 \$2.00

Volume 93, January 1994, 273-279 early stages of inflammation in anti-glomerular basement membrane (GBM) ${ }^{1}$ antibody ( $\mathrm{Ab}$ )-induced glomerulonephritis (GN) (1-3). Among its many actions, IL-1 may contribute to the prominent leukocyte infiltration in anti-GBM Ab GN (4). The latter process depends on specific interactions between adhesion molecules and their ligands present on leukocyte and endothelial cell surfaces. IL-1 promotes leukocyte adhesion by inducing the de novo synthesis of adhesion molecules by endothelial cells, as well as by increasing the affinity of the corresponding leukocyte ligands (5).

Of the numerous cell adhesion molecules, we chose to study the interaction between lymphocyte function-associated molecule-1 (LFA-1, CD1 1a/CD18) and its ligand, intracellular adhesion molecule-1 (ICAM-1), because of the availability of specific monoclonal antibodies. LFA-1 is a cell adhesion molecule whose expression is limited to leukocytes. It is a member of the integrin family and is constitutively expressed on PMNs, B and T lymphocytes (5), and most monocytes, with the exception of some tissue macrophages $(6,7)$. Monocytes, but not PMNs, can increase LFA-1 expression twofold in response to $\mathrm{C} 5 \mathrm{a}$, leukotriene $\mathrm{B}_{4}$, and TNF (8). By comparison, ICAM-1 can be expressed on a wide variety of cells including mesangial (9) and glomerular endothelial cells (10). The low basal expression of ICAM-1 on vascular endothelial cells is rapidly upregulated by cytokines, including IL-1, TNF, and interferon $\gamma(11,12)$.

The cloning and expression of a specific IL-1 receptor antagonist (IL-1 ra) offer an opportunity to study the role of IL-1 on leukocyte accumulation in anti-GBM Ab GN. The recombinant IL-1 ra, a 17-kD protein, competes with IL-1 for binding to its receptors and, in doing so, blocks the activity of IL-1 (13). Two families of IL-1 receptors have been identified. The IL-1 type I receptor is an $80-\mathrm{kD}$ protein present on $\mathrm{T}$ cells, fibroblast, and endothelial cells $(14,15)$, while the type II receptor is a $68-\mathrm{kD}$ protein found on $\mathrm{B}$ cells, macrophages, and neutrophils (16). The IL-1 ra differs in its ability to block the binding of IL-1 to these two receptors. It blocks binding to the type I receptor at nearly equimolar concentrations, whereas a 10-50-M excess is required to block its binding to type II receptors (4). Nonetheless, the administration of IL-1 ra can attenuate a number of systemic responses associated with inflammation (17). This study was undertaken to examine whether selective blockade of IL-1 receptors could reduce the severity of anti-GBM Ab GN, an effect which might involve selective re-

1. Abbreviations used in this paper: $\mathrm{Ab}$, antibody; $\mathrm{C} 3$, third component of complement; ELAM-1, endothelial leukocyte adhesion molecule-1; GAPDH, glyceraldehyde-3-phosphate dehydrogenase; GBM, glomerular basement membrane; GN, glomerulonephritis; ICAM-1, intracellular adhesion molecule-1; IL-1 ra, IL-1 receptor antagonist; LFA-1, lymphocyte function-associated molecule-1; NRS, normal rabbit serum; PADGEM, platelet activation-dependent granule external membrane protein. 
duction of leukocyte infiltration by interfering with IL-1-associated effects on inflammatory cell adhesion.

\section{Methods}

Preparation of anti-GBM Ab and normal rabbit serum (NRS). AntiGBM Ab was prepared by immunizing New Zealand White rabbits with rat GBM as described previously (18). NRS was obtained by bleeding naive, unimmunized rabbits. Nanogram quantities of endotoxin present within the anti-GBM Ab and NRS were removed by incubation of the serum with Pyrofree III endotoxin affinity matrix (Alerchek, Inc., Portland, ME). Endotoxin was not detected by the limulus amoebocyte assay at concentrations above $3 \mathrm{pg} / \mathrm{ml}$ in either the anti-GBM Ab or NRS after Pyrofree III treatment.

Experimental design. Female Lewis rats ( The Scripps Research Institute Breeding Colony) weighing 150-170 g were used for these experiments. A 24-h urine was collected to quantitate baseline proteinuria on day 1 . The animals were divided into four groups, with group I $(n=11)$ receiving anti-GBM $\mathrm{Ab}(0.5 \mathrm{ml})$ intravenously and $0.9 \%$ saline vehicle subcutaneously. Group II $(n=11)$ rats were given antiGBM Ab $(0.5 \mathrm{ml})$ and the IL-1 ra in $0.9 \%$ saline. Groups III $(n=10)$ and IV $(n=11)$ rats received $0.5 \mathrm{ml}$ NRS intravenously and either $0.9 \%$ saline (group III) or the IL-1 ra (group IV). IL-1 ra ( $1 \mathrm{mg}$ ) or $0.9 \%$ saline was administered subcutaneously at $-1,1.5,4,8,12$, and $18 \mathrm{~h}$ after anti-GBM Ab or NRS injection. The effect of IL-1 ra on the course of anti-GBM Ab GN was studied at two time points, 4 and $24 \mathrm{~h}$. 20 rats ( 5 from each group) were killed $4 \mathrm{~h}$ after anti-GBM Ab or NRS administration. The remaining rats $(n=23)$ were killed at $24 \mathrm{~h}$. In these rats, 24-h urine and sera were collected for protein and creatinine determination, respectively. The former was quantitated by the sulfosalicylic method (19) and the latter by a commercial kit according to the directions of the manufacturer (Sigma Chemical Co., St. Louis, MO).

A second study was performed to determine if a higher dose of the IL-1 ra could further decrease PMN infiltration at $4 \mathrm{~h}$. Group VI ( $n$ $=3$ ) rats were administered a total of $30 \mathrm{mg} \mathrm{IL-1} \mathrm{ra} \mathrm{subcutaneously,}$ divided into five doses of $6 \mathrm{mg}$ each at hourly intervals from -1 to $3 \mathrm{~h}$. Control rats (group V, $n=3$ ) were given $0.9 \%$ saline. Both groups received $0.5 \mathrm{ml}$ anti-GBM $\mathrm{Ab}$ at $0 \mathrm{~h}$ and were killed $4 \mathrm{~h}$ after $\mathrm{Ab}$ administration.

To determine whether the protective effect of IL-1 ra could be overcome by increasing the anti-GBM Ab dose, a third study was performed in which rats were given $1 \mathrm{ml}$ anti-GBM Ab intravenously. Group VII rats $(n=3)$ were given $0.9 \%$ saline subcutaneously at $-1,0$, 1,2 , and $3 \mathrm{~h}$ after anti-GBM Ab injection, while group VIII rats $(n=3)$ received $6 \mathrm{mg} \mathrm{IL-1} \mathrm{ra} \mathrm{at} \mathrm{the} \mathrm{same} \mathrm{time} \mathrm{points.} \mathrm{Both} \mathrm{groups} \mathrm{were} \mathrm{killed}$ at $4 \mathrm{~h}$.

Determination of plasma IL-1ra concentration. At the time of killing, $1.5 \mathrm{ml}$ of blood was obtained from the inferior vena cava of all rats and was placed in a tube containing EDTA (Becton Dickinson Vacutainer Systems, Rutherford, NJ) to prevent coagulation. After centrifugation, the plasma was frozen at $-70^{\circ} \mathrm{C}$. Plasma IL-1ra levels were assayed by an antigen capture ELISA, as described previously (20). Briefly, samples were sequentially incubated with an affinity-purified rabbit polyclonal $\mathrm{Ab}$ raised against human recombinant IL-1 ra, biotinylated murine anti-rabbit IgG, and horseradish peroxidase conjugated to avidin. The limit of detection of the assay was $6 \mathrm{ng} / \mathrm{ml}$. All samples were assayed in triplicate.

Quantitation of anti-GBM Ab binding. A paired-label isotope study was performed to ensure that IL-1 ra did not interfere with anti-GBM $\mathrm{Ab}$ binding. Gamma globulin fractions of the anti-GBM serum and NRS were prepared by precipitation with saturated ammonium sulfate and then were labeled with ${ }^{125} I$ and ${ }^{131} I$, respectively (21). Mixtures containing $60 \mu \mathrm{g}$ of each protein were administered intravenously to six rats. The rats were divided into two groups $(n=3)$ and received either $0.9 \%$ saline or IL-1 ra subcutaneously, as described above. The rats were killed at $24 \mathrm{~h}$. After perfusion of the kidneys with $0.9 \%$ saline through the right ventricle and abdominal aorta, the kidneys were re- moved and weighed, and the radioactivity was quantitated. Proteinbound counts in the plasma were determined by precipitation in a final concentration of $10 \%$ TCA. The specific uptake was calculated as described previously (22).

Morphologic studies. At the time of killing, renal tissue samples were fixed in $10 \%$ formalin for light microscopy or were snap-frozen in liquid nitrogen with Tissue-Tek (Miles Laboratories Inc., Elkhart, IN) for immunocytochemistry and immunofluorescence microscopy. Histologic examination was performed on paraffin sections $(2-3 \mu \mathrm{m})$ stained with the periodic acid-Schiff reaction and hematoxylin counterstain. 35 glomeruli in full cross section from each kidney were examined without knowledge of the treatment group and the number of PMNs determined.

Immunocytochemical studies were performed on frozen sections $(3 \mu \mathrm{m})$ that were fixed in acetone. Nonspecific binding was blocked by treating with normal rabbit serum (1:20) for $30 \mathrm{~min}$. The sections were then sequentially incubated with an mAb to ICAM-1 (Seikagaku Kogyo, Inc., Tokyo, Japan ) (10), rabbit anti-mouse IgG, and horseradish peroxidase-mouse antiperoxidase complex (Dako Corp., Carpinteria, CA). The reaction was developed with 3,3'-diaminobenzidine-tetrahydrochloride (Vector Labs, Inc., Burlingame, CA) and was counterstained with hematoxylin (Sigma Chemical Co., St. Louis, MO). Induction of ICAM-1 expression was assessed by estimating the number of capillary loops that expressed ICAM-1 within each of 25 glomerular cross sections. A semiquantitative scale was used to score ICAM-1 expression in which $0=$ no ICAM- 1 staining; $1+=1-5$ capillary loops $/$ glomerulus; $2+=6-10$ capillary loops $/$ glomerulus; $3+=11-15$ capillary loops/glomerulus; and $4+=\geq 16$ capillary loops/glomerulus. All examinations were performed in a blinded manner.

For immunofluorescence microscopy, 3-5- $\mu \mathrm{m}$ cryostat sections were fixed in ether-ethanol or acetone and were stained with fluoresceinated Abs specific for rabbit IgG, rat fibrinogen, and the third component of complement (C3) (Cappel Research Products Division, Organon Teknika Corp., Durham, NC). Anti-rabbit IgG and rat C3 were assessed for intensity and distribution, with the former graded from 0 to $4+$. Intraglomerular fibrin deposits were graded as either absent or present, with 45-55 glomeruli examined per animal. For the localization of mAb ED-1 and lymphocyte function-associated molecule-1 $\beta$ (LFA-1 $\beta)$, (CD18)-staining cells, indirect immunofluorescence microscopy was performed with mAbs to rat ED-1 (Harlan Bioproducts for Science, Inc., Indianapolis, IN) and LFA-1 $\beta$ (Seikagaku Kogyo, Inc.) (23). Sections were incubated with a predetermined dilution of each $\mathrm{mAb}$, followed by fluoresceinated goat anti-mouse IgG that had been absorbed with rabbit and rat IgG. ED-1 and LFA-1 $\beta$ expression were quantitated by counting the number of ED-1 and LFA-1 $\beta$-staining cells in 25 glomerular cross sections.

Quantitation of steady state glomerular mRNA expression. Glomeruli were isolated by sequential sieving through No. 60 and No. 100 mesh wire screens. The glomeruli collected on the No. 200 mesh screen contained $<10 \%$ tubular contamination. After washing with $0.9 \%$ saline, the glomeruli were homogenized in $4 \mathrm{M}$ guanidine isothiocyanate with a sonicator (Heat Systems-Ultrasonics, Inc., Plainview, NY). The RNA was prepared by cesium chloride centrifugation, was quantitated by its absorption at $260 \mathrm{~nm}$, and then was frozen at $-70^{\circ} \mathrm{C}$.

$2 \mu \mathrm{g}$ of glomerular total RNA was hybridized with $10^{5}$ counts of each $\left[{ }^{32} \mathrm{P}\right]$ UTP-labeled rat antisense riboprobe at $56^{\circ} \mathrm{C}$ for $12-14 \mathrm{~h}$. The preparation of the $\left[{ }^{32} \mathrm{P}\right]$ UTP-labeled rat riboprobes for $\mathrm{IL}-1 \beta$, $\mathrm{TNF} \alpha$, and glyceraldehyde-3-phosphate dehydrogenase (GAPDH) (gift of Dr. Ray Wu, Cornell University, Ithaca, NY) has been described previously (24). Unhybridized RNA was digested with RNase T1 (Ambion Inc., Austin, TX) and RNase A (Sigma Chemical Co.) at $30^{\circ} \mathrm{C}$ for $1 \mathrm{~h}$. The RNase was then digested with proteinase $\mathrm{K}, 10$ $\mathrm{mg} / \mathrm{ml}$ for $30 \mathrm{~min}$ at $37^{\circ} \mathrm{C}$. After phenol-chloroform extraction and sodium acetate-ethanol precipitation, the samples were electrophoresed on $6 \%$ polyacrylamide gel.

The dried radioactive blots were scanned on a radioanalytic imaging system (AMBIS Inc., San Diego, CA) for 4-6 h. The blot was computer regenerated on the monitor and rectangles were drawn to 
circumscribe the detected bands. The amount of radioactivity present within each rectangle was determined, corrected for background counts, and normalized to a square centimeter. The data are presented as a ratio of specific mRNA/GAPDH mRNA to ensure a constant quantity of RNA in each sample.

Statistical methods. All data are presented as the mean \pm SD. Statistical analyses were performed by ANOVA. Then, significant differences were analyzed by comparing individual group means using the unpaired Student's $t$ test. For data that were not normally distributed, analyses were performed by the Wilcoxon rank sum. A $P<0.05$ was defined as statistically significant.

\section{Results}

Morphology. $4 \mathrm{~h}$ after the administration of anti-GBM Ab, the rats developed a diffuse infiltrative/proliferative $G N$ composed predominantly of PMNs which receded by $24 \mathrm{~h}$ (Table I), leaving a residual mononuclear leukocyte infiltration. The mean number of infiltrating PMNs per glomerulus at $4 \mathrm{~h}$ was $9.8 \pm 1.9$ in the rats treated with saline (group I). The administration of the IL-1 ra resulted in a $38.5 \%$ decline to $6.0 \pm 1.5$ PMN/glomerulus (group II, $P<0.001$ ) ( Table I). By comparison, the two groups treated with NRS had 1.0 \pm 0.3 (group III) and 1.0 \pm 0.3 (group IV) PMN/glomerulus.

Immunofluorescence microscopy. Control rats that were administered NRS with either $0.9 \%$ saline (group III) or IL-1 ra (group IV) had no evidence of immunofluorescent staining with either anti-rabbit IgG, rat $\mathrm{C} 3$, or fibrinogen Abs. In contrast, there were diffuse 4+ linear deposits of rabbit IgG and rat C3 along the GBM in both groups I and II rats. The staining between these two groups was indistinguishable at both 4 and $24 \mathrm{~h}$. Fibrin deposits were seen within $<5 \%$ of the glomerular capillary lumens, with a variation in intensity among capillary loops and glomeruli. There were no differences in glomerular fibrin deposits between groups I and II rats at either 4 or $24 \mathrm{~h}$. Similar results were obtained for rabbit IgG, rat C3, and glomerular fibrin staining for groups $\mathrm{V}$ and $\mathrm{VI}$ in the two high dose IL-1 ra studies.

Indirect immunofluorescence microscopy staining for ED1 revealed that the number of monocytes infiltrating the glomerulus was reduced $28.6 \%$ from $4.9 \pm 0.8$ (group I) to $3.5 \pm 0.8$ (group II) at $4 \mathrm{~h}$ with IL-1 ra treatment $(P=0.002)$ (Fig. $1, A$ and $B$ ). Both values were significantly greater than those in groups III (1.2 \pm 0.4$)$ and IV ( $1.4 \pm 0.4)$ rats (Table I). At $24 \mathrm{~h}$, there was an increase in ED-1 staining to 7.5 \pm 1.4 cells / glomerulus in rats from group $\mathrm{I}$, which decreased $17.3 \%$ to $6.2 \pm 1.0$ cells/glomerulus in rats treated with IL-1 ra (group II, $P$ $<0.001$ ).

The reduction in infiltrating PMNs and macrophages at $4 \mathrm{~h}$ was accompanied by a $38.5 \%$ reduction in cells expressing LFA- $1 \beta$ in rats given anti-GBM Ab and treated with IL-1 ra ( $10.7 \pm 1.6$ cells/glomerulus) when compared with those given $\mathrm{Ab}$ and control $0.9 \%$ saline $(16.7 \pm 1.9$ cells/glomerulus, $P$ $=0.0001$ ) (Fig. 1, C and D). By comparison, rats in both control groups (III and IV) that received NRS had $1.1 \pm 0.4$ LFA-1-positive cells/glomerulus (Table I). The number of cells within the glomerulus expressing LFA- $1 \beta$ at $24 \mathrm{~h}$ in group I rats declined from $16.7 \pm 1.9$ cells/glomerulus to $8.5 \pm 1.1$, reflecting a decrease in the number of infiltrating PMNs. Treatment with IL-1 ra resulted in an additional $16 \%$ reduction in LFA-1 staining in group II rats $(7.1 \pm 1.0, P<0.003)$.

There was a constitutive low level immunolabeling for ICAM-1 within the endothelial cells of the arterioles and intertubular capillaries of the normal kidney. In addition, there was a variable segmental capillary wall staining within the glomerulus. However, the source of ICAM-1 within the glomerulus could not be determined by light microscopy, but has been demonstrated previously by immunoelectron microscopy to arise from endothelial and epithelial cells of Bowman's capsule (10). Control rats treated with NRS and either $0.9 \%$ saline or IL-1 ra had a similar pattern and degree of staining for ICAM-1 at $4 \mathrm{~h}$. By comparison, rats given anti-GBM Ab and $0.9 \%$ saline (group I) had increased ICAM-1 staining that decreased with IL-1 ra treatment. Fig. 2, $A$ and $B$ are representative photomicrographs of ICAM-1 staining in anti-GBM Ab GN which demonstrate our grading system. The mean glomerular ICAM-1 score for the two control groups treated with NRS was $0.8 \pm 0.2$, while for those with anti-GBM Ab GN (Fig. 3), it was $2.5 \pm 0.2$ (range 2.3-2.7). The administration of IL-1 ra decreased the glomerular ICAM-1 score to $2.0 \pm 0.2(P<0.05)$ ( range $1.2-$ $2.4)$, although two rats had scores $(2.3,2.4)$ that crossed over into the group that was administered anti-GBM Ab and $0.9 \%$ saline. However, by $24 \mathrm{~h}$, the glomerular ICAM-1 score had segregated between the two groups (Fig. 3). There was an increase in the mean score of group I rats to $3.1 \pm 0.2$ (range 2.8$3.2)$ compared with $2.5 \pm 0.1(P=0.0001)$ with IL-1 ra treatment (range 2.4-2.7).

Table I. Glomerular Leukocyte Infiltration 4 h after Anti-GBM Ab or NRS Administration

\begin{tabular}{|c|c|c|c|}
\hline Group & PMN & Macrophage & LFA- $1 \beta$ \\
\hline \multicolumn{4}{|l|}{ Standard dose } \\
\hline I. Anti-GBM Ab $+0.9 \%$ saline & $9.8 \pm 1.9^{* \neq \S}$ & $4.9 \pm 0.8^{* \neq \S}$ & $16.7 \pm 1.9^{* \neq \S}$ \\
\hline II. Anti-GBM Ab + IL-1 ra & $6.0 \pm 1.5^{\| 1}$ & $3.5 \pm 0.8^{\|\|}$ & $10.7 \pm 1.6^{111}$ \\
\hline III. NRS + $0.9 \%$ saline & $1.0 \pm 0.3$ & $1.2 \pm 0.4$ & $1.1 \pm 0.4$ \\
\hline IV. NRS + IL-1 ra & $1.0 \pm 0.3$ & $1.4 \pm 0.4$ & $1.1 \pm 0.4$ \\
\hline \multicolumn{4}{|l|}{ High dose IL-1 ra } \\
\hline V. Anti-GBM Ab $+0.9 \%$ saline & $9.2 \pm 1.4^{* *}$ & $4.4 \pm 1.0^{* *}$ & ND \\
\hline VI. Anti-GBM + Ab IL-1 ra & $6.2 \pm 1.0$ & $3.3 \pm 1.1$ & ND \\
\hline \multicolumn{4}{|c|}{ High dose anti-GBM Ab + high dose IL-1 ra } \\
\hline VII. Anti-GBM Ab $+0.9 \%$ saline & $18.6 \pm 2.4$ & $4.0 \pm 1.0$ & ND \\
\hline VIII. Anti-GBM Ab + IL-1 ra & $19.2 \pm 2.6$ & $4.6 \pm 1.1$ & ND \\
\hline
\end{tabular}

${ }^{*} P<0.05$ I vs II; ${ }^{\ddagger} P<0.05$ I vs III; ${ }^{\S} P<0.05$ I vs IV; $" P<0.05$ II vs III; $\quad P<0.05$ II vs IV; ${ }^{* *} P<0.05$ V vs VI; ND, not determined. 

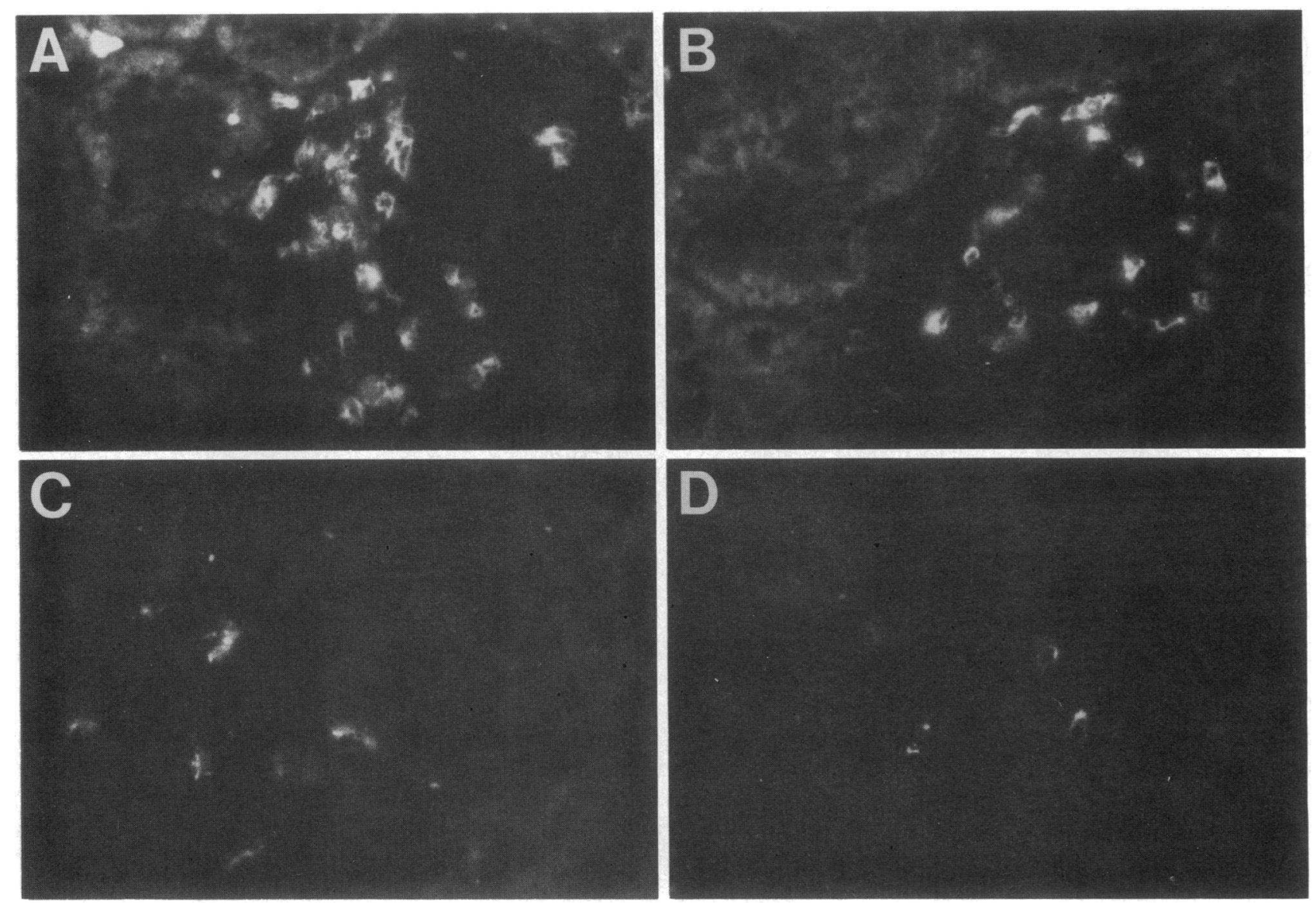

Figure 1. This figure shows representative photomicrographs of immunofluorescent staining for monocyte/macrophage (ED- $1+$ cells, $A$ and $B$ ) and cells expressing LFA- $1 \beta$ ( $C$ and $D) 4 \mathrm{~h}$ after anti-GBM Ab GN induction. The rats in $A$ and $C$ received $0.9 \%$ saline, while $B$ and $D$ represent rats treated with IL-1 ra.

Quantitation of anti-GBM Ab binding. In paired-label radioisotope studies, IL-1 ra did not interfere with binding of the anti-GBM Ab. Rats treated with IL-1 ra bound $0.330 \pm 0.009$ $\mu \mathrm{g} /$ kidney, which was similar to control rats treated with $0.9 \%$ saline $(0.329 \pm 0.013 \mu \mathrm{g} /$ kidney $)$ at the 60 -mg test dose used.

Functional studies. The serum creatinine measured at $24 \mathrm{~h}$ was similar among the four groups as rats with anti-GBM $\mathrm{Ab}$ GN did not develop azotemia at this early time point. The serum creatinine in the two groups with anti-GBM Ab GN were $0.5 \pm 0.1$ (group I) and $0.4 \pm 0.1$ (group II) $\mathrm{mg} / \mathrm{dl}$, while the values in control rats were $0.4 \pm 0.1$ (group III) and $0.4 \pm 0.1$ (group IV) $\mathrm{mg} / \mathrm{dl}$.

The 24-h urinary protein excretion in all rats before the experiment was $<5 \mathrm{mg}$. Rats in groups III and IV remained free of proteinuria $(<5 \mathrm{mg} / 24 \mathrm{~h})$. By comparison, rats given anti-GBM $A b$ and $0.9 \%$ saline (group I) had urinary protein excretion of $147 \pm 34 \mathrm{mg} / 24 \mathrm{~h}$. IL-1 ra treatment (group II) produced a reduction in proteinuria to $75 \pm 25 \mathrm{mg} / 24 \mathrm{~h}(P$ $<0.002$ ).

Plasma concentration of IL-1 ra. At $4 \mathrm{~h}$, the plasma IL-1 ra concentrations were $2,659 \pm 1,636$ and $1,984 \pm 1,059 \mathrm{ng} / \mathrm{ml}$ in groups II and IV $(P=\mathrm{NS})$, respectively, which declined to $87 \pm 88$ and $27 \pm 22 \mathrm{ng} / \mathrm{ml}$, respectively, at $24 \mathrm{~h}$. There was a significant difference in plasma IL-1 ra concentrations between the 4- and 24-h values. These differences may be attributed to the schedule of IL-1 ra administration in which the 4-h plasma concentration was determined $2.5 \mathrm{~h}$ after the last IL-1 ra dose, while the 24-h plasma level reflects a dose given $6 \mathrm{~h}$ earlier. IL-1 ra was not detected in the plasma of the saline-injected groups I and III rats at either time point.

Effect of IL-1 ra on steady state glomerular mRNA expression. The steady state IL-1 $\beta /$ GAPDH mRNA ratio in groups I $(1.49 \pm 0.44)$ and II $(1.27 \pm 0.40)$ was similar at $4 \mathrm{~h}$, but was no longer detected at $24 \mathrm{~h}$. IL-1 $\beta$ transcripts were not detectable in groups III and IV rats at either 4 or $24 \mathrm{~h}$. Similarly, there were no detectable transcripts for TNF $\alpha$ in groups III or IV rats at either 4 or $24 \mathrm{~h}$. By comparison, group I rats had a TNF $\alpha$ / GAPDH steady state mRNA ratio of $0.27 \pm 0.05$ at $4 \mathrm{~h}$ after anti-GBM Ab administration, which became undetectable by $24 \mathrm{~h}$. This ratio was not significantly different from rats treated with IL-1 ra $(0.24 \pm 0.05)$.

High dose IL-1 ra study. Two additional studies were performed to examine the IL-1 ra effect on PMN infiltration at $4 \mathrm{~h}$. In both studies, IL-1 ra was administered hourly with an increase in the total dose to $30 \mathrm{mg}, 15$-fold greater than the cumulative $4-\mathrm{h}$ dose in the first study $(2 \mathrm{mg})$. The dose of antiGBM Ab was doubled to $1.0 \mathrm{ml}$ in the third study. Despite a 16-fold increase in the plasma IL-1ra concentration to $39,970 \pm 5,215 \mathrm{ng} / \mathrm{ml}$ in the second study (standard $0.5 \mathrm{ml}$ anti-GBM Ab), there was no additional benefit afforded by IL-1 ra (Table I). The mean number of PMNs infiltrating each glomerulus decreased $32.4 \%$ to $6.2 \pm 1.0$ from $9.2 \pm 1.4$ ( $P$ 

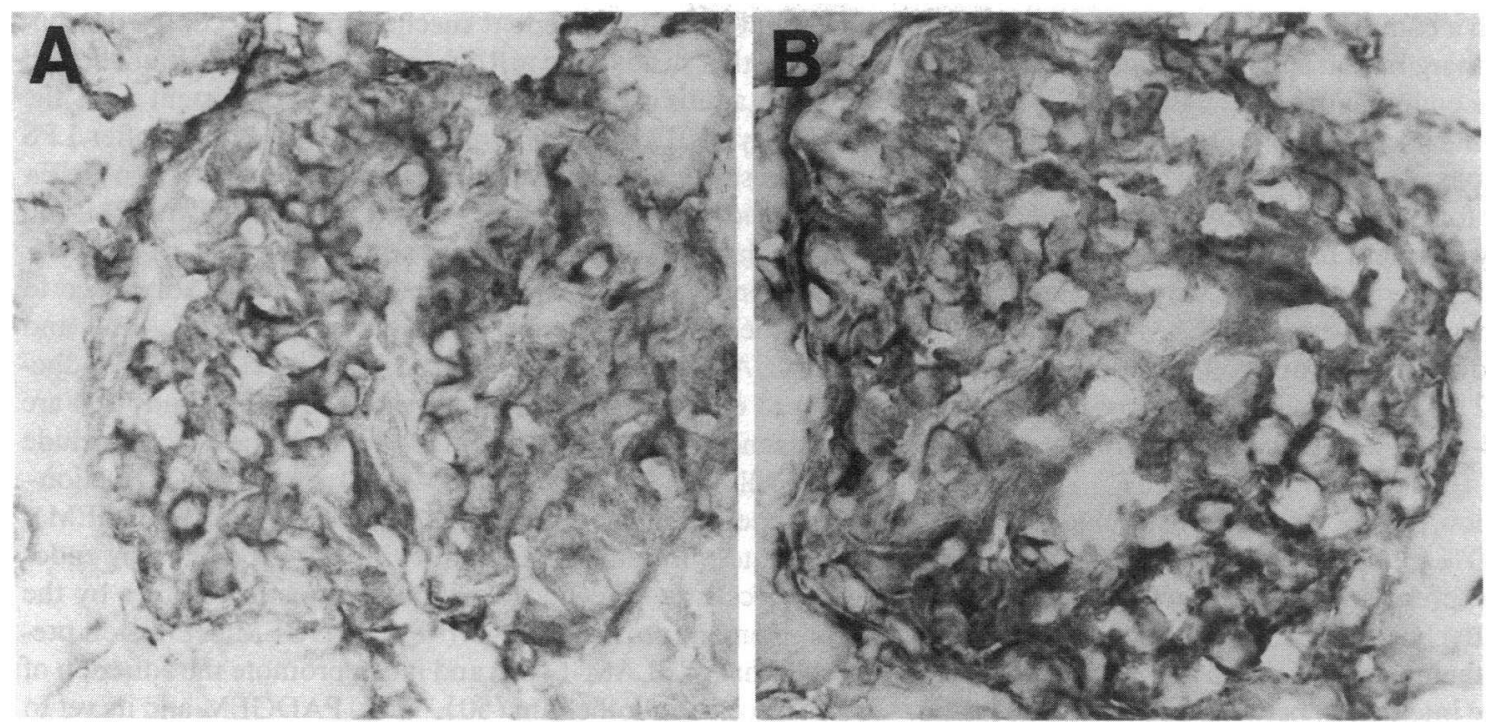

Figure 2. The ICAM staining of glomeruli $4 \mathrm{~h}$ after anti-GBM Ab administration is shown. The glomeruli in $A$ (IL-1 ra) and $B(0.9 \%$ saline $)$ were scored $2+$ and $4+$, respectively. A semiquantitative scoring system was devised in which $0=$ no ICAM-1 staining, $1+=1-5$ capillary loop/glomerulus, $2+=6-10$ capillary loop/glomerulus, $3+=11-15$ capillary loop/glomerulus, and $4+=\geq 16$ capillary loop/glomerulus. This grading scale was used to produce the data shown in Fig. 3.

$<0.002$ ) with the higher dose of IL-1 ra. The amelioration of macrophage infiltration also did not improve with the higher dose of IL-1 ra. There was a $25 \%$ decrease in ED-1 staining cells from $4.4 \pm 1.0$ to $3.3 \pm 1.1(P=0.01)$.

The administration of a higher dose of the anti-GBM Ab ( 1 $\mathrm{ml}$ ) resulted in an increase in PMN infiltration at $4 \mathrm{~h}$ and negated the protective effect of IL-1 ra on PMN infiltration ( Table I), despite a plasma IL-1 ra concentration of $42,303 \pm 9,809$ $\mathrm{ng} / \mathrm{ml}$ in group VIII rats. Interestingly, group VII rats treated with $0.9 \%$ saline had plasma IL-1 ra concentrations of $15 \pm 4$ $\mathrm{ng} / \mathrm{ml}$, indicating the presence of an endogenous IL-1 ra response. The number of PMNs infiltrating the glomerulus increased twofold with a doubling of the anti-GBM Ab administered (Table I). The intensity of the inflammatory response appeared to have overshadowed the benefit of the IL-1 ra noted with the lower dose model, since there were no differences in the number of PMNs infiltrating the glomerulus at $4 \mathrm{~h}$ between those that had received IL-1 ra (19.2 $\pm 2.6 \mathrm{PMN} /$ glomerulus $)$ or

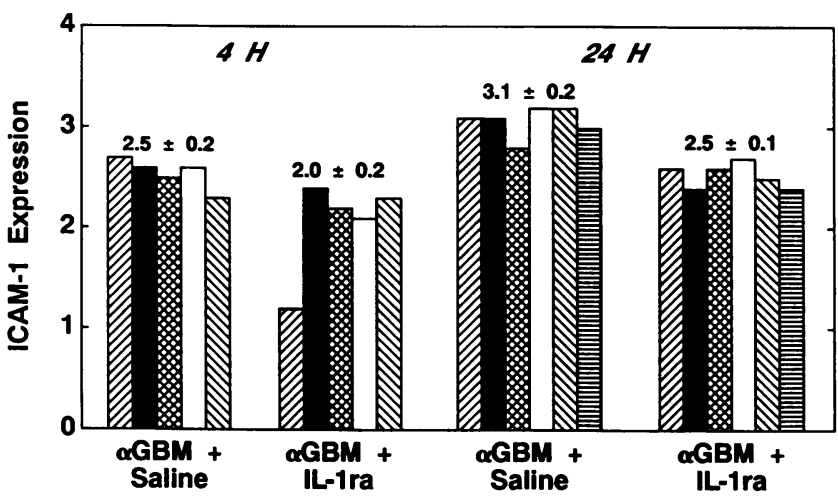

Figure 3. Semiquantitative estimation of glomerular ICAM-1 expression in anti-GBM Ab GN and control rats treated with either IL-1 ra or $0.9 \%$ saline at 4 and $24 \mathrm{~h}$. The data are based on the grading scale outlined in Fig. 2.
$0.9 \%$ saline ( $18.6 \pm 2.4 \mathrm{PMN} /$ glomerulus). Similarly, the number of cells staining for ED-1 per glomerulus also did not differ significantly between the two groups, $4.6 \pm 1.1$ vs $4.0 \pm 1.0$, respectively. 24-h urinary protein excretion could not be determined in these two studies since the endpoint of the experiments was $4 \mathrm{~h}$.

\section{Discussion}

We demonstrated that specific blockade of IL-1 activity with its receptor antagonist could attenuate leukocyte accumulation in anti-GBM Ab GN, thereby confirming a role for IL-1 in the pathogenesis of glomerular inflammation in this model. The administration of IL-1 ra during the heterologous phase of a moderately severe anti-GBM Ab GN was associated with $\sim 39$ and $29 \%$ declines in the number of PMNs and monocytes, respectively, infiltrating the glomerulus at $4 \mathrm{~h}$. These declines were associated with a $39 \%$ reduction of cells expressing LFA$1 \beta$ and an $\sim 20 \%$ reduction in the glomerular expression of its ligand, ICAM-1. These pathologic changes at $4 \mathrm{~h}$, in turn, correlated with an $\sim 50 \%$ reduction in 24-h urinary protein excretion. Not surprisingly, because of the complexity of stimuli for PMN infiltration, the beneficial effects of the IL-1 ra could be overcome by increasing the severity of the glomerulonephritic process by increasing the dose of the anti-GBM Ab. Interestingly, IL-1 ra was detected in the plasma of the salinetreated high dose rats. This suggests increased endogenous IL1 ra production by these rats and may reflect an attempt to downregulate IL-1-induced inflammation. This would be consistent with the presence of IL-1 ra mRNA in the glomeruli of rats with anti-GBM Ab GN ( Tang, W. W., L. Feng, and C. B. Wilson, unpublished observations).

That IL-1 blockade should affect leukocyte infiltration is to be expected given the pleotropic properties of this cytokine. IL-1 enhances PMN accumulation by promoting the generation of factors that are chemotactic for PMN including IL-8 $(25,26)$. Once attracted to a site of inflammation, PMN adhe- 
sion occurs through a complex and as yet incompletely understood process. The margination and initial attachment of circulating PMNs to the endothelium are mediated by a family of proteins known as the selectins (27), of which endothelial leukocyte adhesion molecule-1 (ELAM-1) is a member $(28,29)$. The PMN receptor for ELAM-1 remains to be identified, but is believed to be a glycoprotein or glycolipid containing a sialylLewis ${ }^{\mathrm{x}}$ carbohydrate determinant $(30,31)$. Vascular endothelial cells do not constitutively express ELAM-1; however, IL-1 stimulates the de novo synthesis and cell membrane expression of this molecule (32). The expression is rapid, occurring within $30 \mathrm{~min}$, peaks at 4-6 h, and declines to basal level by 12-24 h (29).

After margination, leukocyte integrins including LFA-1, Mac-1 (CD1 1b/CD18), and p150,95 (CD11c/CD18), which are constitutively expressed as inactive proteins, are qualitatively and quantitatively activated. Once activated, leukocytes are able to bind to their endothelial adhesins. Of the three leukocyte integrins, the interaction between LFA-1 and its ligand, ICAM-1, has been the most extensively studied. The availability of mAbs to LFA-1 and ICAM-1 enabled us to study this interaction in anti-GBM Ab GN. The binding of LFA-1 and ICAM-1 results in adhesion and migration of PMN through the endothelium (33). In contrast to ELAM-1, ICAM-1 appears within 2-3 h, although its peak expression is not seen until $24 \mathrm{~h}$ after stimulation by IL-1 (34). This latter finding may account for the heterogeneity of glomerular ICAM-1 expression at $4 \mathrm{~h}$ in which the score of two rats administered IL-1 ra crossed over into group I, while there was complete segregation of the ICAM-1 scores at $24 \mathrm{~h}$.

The decline in glomerular ICAM-1 expression was associated with a decrease in glomerular leukocyte infiltration at 4 and $24 \mathrm{~h}$ in rats treated with IL-1 ra. This is consistent with a previous study demonstrating attenuation of glomerular leukocyte infiltration in anti-GBM Ab GN with the administration of a neutralizing Ab to ICAM-1 (35). Our data are also consistent with in vitro observations in which pretreatment of endothelial cells with IL-1 ra blocks the adhesion of PMN to endothelial cells (36). However, our data differ from that reported by Mulligan et al. (37), in which IL-1 ra did not affect glomerular neutrophil infiltration or urinary protein excretion. This discrepancy likely reflects differences in the severity of anti-GBM $\mathrm{Ab}$ GN as well as in the frequency and quantity of IL-1 ra administered. The latter may be of critical importance since a discordance between the binding of IL-1 ra and suppression of IL-1 activity has been noted. To achieve a therapeutic effect, $>95 \%$ of IL-1 receptors must be blocked, since IL-1 activity can be elicited by binding to $<5 \%$ of its receptors $(38)$. The quantity of IL-1 ra administered in our low dose study exceeds that reported by Mulligan and colleagues by fivefold. More importantly, our dosing regimen insured high plasma concentrations of IL-1 ra within the initial 4-6 h, when IL-1 activity is highest.

A 15-fold increase in the cumulative dose of IL-1 ra administered by $4 \mathrm{~h}$ resulted in an approximate 16-fold increase in plasma IL-1 ra levels. However, an additional benefit, as assessed by a further decrease in the number of infiltrating PMNs and monocytes/macrophages, was not seen. The incomplete protective effect of IL-1 ra could be anticipated, since other inflammatory mediators, including TNF $\alpha$ (32), C5a (39), platelet activating factor $(40)$, and leukotriene $B_{4}(41,42)$, promote PMN adhesion to endothelial cells through both ICAM-1-de- pendent and -independent mechanisms. Indeed, we demonstrated that steady state mRNA levels of TNF $\alpha$ were unaffected by the administration of IL-1 ra. This is consistent with the inability of IL-1 ra to suppress serum TNF activity after LPS administration (43). The absence of an IL-1 ra effect on TNF $\alpha$ expression is of significance, since TNF can activate PMN to upregulate CD18-associated proteins, while IL-1 cannot (44, 45 ). Finally, additional mechanisms for PMN adherence to endothelium exist, since a combination of anti-ELAM-1 and anti-ICAM-1 was only $80 \%$ effective in blocking PMN adhesion to endothelial cells in vitro (46). Several ligands that are independent of IL- 1 activation are being defined. They include intracellular adhesion molecule-2 (47) and platelet activationdependent granule external membrane protein (PADGEM). The latter molecule is of interest since its expression by endothelial cells is upregulated within seconds to minutes by the complement proteins C5b-9 (48). PADGEM expression precedes that of ELAM-1 (49) and it can promote the adhesion of PMN to the endothelium (50). Thus, PADGEM and its yet to be defined ligand may be one of the earliest mechanisms for PMN margination.

In summary, our results demonstrated an increase in ICAM- 1 expression $4 \mathrm{~h}$ after anti-GBM Ab administration. This increase was in part due to IL-1, since treatment with the IL-1 ra decreased ICAM-1 expression, which was associated with a $30-40 \%$ decline in PMN and monocyte infiltration. These histopathologic changes were associated with a $50 \%$ reduction in 24-h urinary protein excretion. Although Abs directed towards ICAM-1 may be of greater efficacy in preventing leukocyte infiltration and proteinuria, the lack of immunogenicity of this recombinant human protein suggest a potential therapeutic role for this agent in anti-GBM Ab GN.

\section{Acknowledgments}

We are grateful to Christopher Smith and Richard Ando in the Immunology Group at Synergen for the measurement of IL-1 ra levels.

This is publication 7703-IMM from the Department of Immunology, The Scripps Research Institute, La Jolla, CA. This work was supported in part by grant DK-20043 from the National Institutes of Health. Statistical analysis was done as part of the General Clinical Research Computing Center award (M01 RR00833). Dr. Tang was the recipient of a fellowship from the National Kidney Foundation of Southern California.

\section{References}

1. Feng, L., W. W. Tang, and C. B. Wilson. 1991. mRNA analysis of dysfunctional glomerular fibrinolysis in anti-glomerular basement membrane antibody glomerulonephritis. J. Am. Soc. Nephrol. 2:540a. (Abstr.)

2. Wiggins, R. C., C. Eldredge, and S. Kunkel. 1987. Monokine production by glomeruli at different stages of crescent formation in the rabbit. Proc. Int. Congr. Nephrol., 10th. 368a. (Abstr.)

3. Tipping, P. G., M. G. Lowe, and S. R. Holdsworth. 1991. Glomerular interleukin 1 production is dependent on macrophage infiltration in anti-GBM glomerulonephritis. Kidney Int. 39:103-110.

4. Dinarello, C. A. 1991. Interleukin-1 and interleukin-1 antagonism. Blood. 77:1627-1652.

5. Springer, T. A. 1990. Adhesion receptors of the immune system. Nature (Lond.). 346:425-434.

6. Kurzinger, K., and T. A. Springer. 1982. Purification and structural characterization of LFA-1, a lymphocyte function-associated antigen and Mac-1, a related macrophage differentiation antigen associated with the type three complement receptor. J. Biol. Chem. 257:12412-12418.

7. Strassmann, G., T. A. Springer, S. J. Haskill, C. C. Miraglia, L. L. Lanier, and D. O. Adams. 1985. Antigens associated with the activation of murine mononuclear phagocytes in vivo: differential expression of lymphocyte function-associated antigen in the several stages of development. Cell. Immunol. 94:265-275. 
8. Miller, L. J., D. F. Bainton, N. Borregaard, and T. A. Springer. 1987. Stimulated mobilization of monocyte Mac-1 and p150,95 adhesion proteins from an intracellular vesicular compartment to the cell surface. J. Clin. Invest. 80:535-544.

9. Denton, M. D., P. A. Marsden, F. W. Luscinskas, B. M. Brenner, and H. R. Brady. 1991. Cytokine-induced phagocyte adhesion to human mesangial cells: role of CD1 1 /CD18 integrins and ICAM-1. Am. J. Physiol. 261:F1071-F1079.

10. Kanagawa, K., H. Ishikura, C. Takahashi, T. Tamatani, M. Miyasaka, M Togashi, T. Koyanagi, and T. Yoshiki. 1991. Identification of ICAM-1-positive cells in the nongrafted and transplanted rat kidney: an immunohistochemical and ultrastructural study. Transplantation (Baltimore). 52:1057-1062.

11. Dustin, M. L., R. Rothlein, A. K. Bhan, C. A. Dinarello, and T. A. Springer. 1986. Induction by IL-1 and interferon-gamma: tissue distribution, biochemistry, and function of a natural adherence molecule (ICAM-1). J. Im munol. 137:245-254.

12. Pober, J. S., L. A. Lapierre, A. H. Stolpen, T. A. Brock, T. A. Springer, W Fiers, M. P. Bevilacqua, D. L. Mendrick, and M. A. Gimbrone, Jr. 1987. Activation of cultured human endothelial cells by recombinant lymphotoxin: comparison with tumor necrosis factor and interleukin 1 species. J. Immunol. 138:33193324.

13. Eisenberg, S. P., R. J. Evans, W. P. Arend, E. Verderber, M. T. Brewer, C. H. Hannum, and R. C. Thompson. 1990. Primary structure and functional expression from complementary DNA of a human interleukin-1 receptor antagonist. Nature (Lond.). 343:341-346.

14. Chizzonite, R., T. Truitt, P. L. Kilian, A. S. Stern, P. Nunes, K. P. Parker, K. Kaff ka, A. O. Chua, D. K. Lugg, and U. Gubler. 1989. Two high-affinity interleukin 1 receptors represent separate gene products. Proc. Natl. Acad. Sci. USA. 86:8029-8033.

15. Horuk, R., J. J. Huang, M. Covington, and R. C. Newton. 1987. A biochemical and kinetic analysis of the interleukin-1 receptor. Evidence for differences in molecular properties of IL-1 receptors. J. Biol. Chem. 262:16275-16278.

16. Dripps, D. J., E. Verderber, R. K. Ng, R. C. Thompson, and S. P. Eisenberg. 1991. Interleukin-1 receptor antagonist binds to the type II interleukin-1 receptor on B cells and neutrophils. J. Biol. Chem. 266:20311-20315.

17. Gershenwald, J. E., Y. Fong, T. J. Fahey III, S. E. Calvano, R. Chizzonite, P. L. Kilian, S. F. Lowry, and L. L. Moldawer. 1990. Interleukin 1 receptor blockade attenuates the host inflammatory response. Proc. Natl. Acad. Sci. USA. 87:4966-4970.

18. Blantz, R. C., and C. B. Wilson. 1976. Acute effects of antiglomerular basement membrane antibody on the process of glomerular filtration in the rat. $J$. Clin. Invest. 58:899-911.

19. Wilson, C. B., and F. J. Dixon. 1970. Antigen quantitation in experimental immune complex glomerulonephritis. I. Acute serum sickness. J. Immunol. 105:279-290.

20. Granowitz, E. V., R. Porat, J. W. Mier, J. P. Pribble, D. M. Stiles, D. C Bloedow, M. A. Catalano, S. M. Wolff, and C. A. Dinarello. 1992. Pharmacokinetics, safety, and immunomodulatory effects of human recombinant interleukin-1 receptor antagonist in healthy humans. Cytokine. 4:353-360.

21. McConahey, P. J., and F. J. Dixon. 1966. A method of trace iodination of proteins for immunologic studies. Int. Arch. Allergy Appl. Immunol. 29:185-189.

22. Wilson, C. B., F. J. Dixon, J. G. Fortner, and G. J. Cerilli. 1971. Glomeru lar basement membrane-reactive antibody in anti-lymphocyte globulin. J. Clin Invest. 50:1525-1535.

23. Tamatani, T., M. Kotani, and M. Miyasaka. 1991. Characterization of the rat leukocyte integrin, CD11/CD18, by the use of LFA-1 subunit-specific monoclonal antibodies. Eur. J. Immunol. 21:627-633

24. Xia, Y., L. Feng, T. Yoshimura, and C. B. Wilson. 1993. LPS-induced MCP-1, IL-1 $\beta$, and TNF $\alpha$ mRNA expression in isolated erythrocyte-perfused rat kidney. Am. J. Physiol. 264:F774-F780.

25. Strieter, R. M., S. L. Kunkel, H. J. Showell, D. G. Remick, S. H. Phan, P. A. Ward, and R. M. Marks. 1989. Endothelial cell gene expression of a neutrophil chemotactic factor by TNF-alpha, LPS, and IL-1 beta. Science (Wash. DC). 243:1467-1469.

26. Mielke, V., J. G. J. Bauman, M. Sticherling, T. Ibs, A. G. Zomershoe, K. Seligmann, H.-H. Henneicke, J.-M. Schroder, W. Sterry, and E. Christophers. 1990. Detection of neutrophil-activating peptide NAP/IL-8 and NAP/IL-8 mRNA in human recombinant IL-1 alpha and human recombinant tumor necrosis factor alpha stimulated human dermal fibroblasts. An immunohistochemical and fluorescent in situ hybridization study. J. Immunol. 144:153-161.

27. McEver, R. P. 1991. Leukocyte interactions mediated by selectins. Thromb. Haemostasis. 66:80-87.

28. Bevilacqua, M. P., J. S. Pober, M. E. Wheeler, R. S. Cotran, and M. A. Gimbrone, Jr. 1985. Interleukin 1 acts on cultured human vascular endothelium to increase the adhesion of polymorphonuclear leukocytes, monocytes, and related leukocyte cell lines. J. Clin. Invest. 76:2003-2011.

29. Bevilacqua, M. P., J. S. Pober, D. L. Mendrick, R. S. Cotran, and M. A.
Gimbrone, Jr. 1987. Identification of an inducible endothelial-leukocyte adhesion molecule. Proc. Natl. Acad. Sci. USA. 84:9238-9242.

30. Bevilacqua, M. P., S. Stengelin, M. A. Gimbrone, Jr., and B. Seed. 1989. Endothelial leukocyte adhesion molecule 1: an inducible receptor for neutrophils related to complementary regulatory proteins and lectins. Science (Wash. DC). 243:1160-1165.

31. Phillips, L. M., E. Nudelman, F. C. Gaeta, M. Perez, A. K. Singhal, S.-I. Hakomori, and J. C. Paulson. 1990. Elam-1 mediates cell adhesion by recognition of a carbohydrate ligand, Sialyl-Le ${ }^{x}$. Science (Wash. DC). 250:1130-1132.

32. Pober, J. S., M. P. Bevilacqua, D. L. Mendrick, L. A. Lapierre, W. Fiers, and M. A. Gimbrone, Jr. 1986. Two distinct monokines, interleukin 1 and tumo necrosis factor, each independently induce biosynthesis and transient expression of the same antigen on the surface of cultured human vascular endothelial cells. $J$. Immunol. 136:1680-1687.

33. Lawrence, M. B., C. W. Smith, S. G. Eskin, and L. V. McIntire. 1990. Effect of venous shear stress on CD18-mediated neutrophil adhesion to cultured endothelium. Blood. 75:227-237.

34. Pober, J. S., M. A. Gimbrone, Jr., L. A. Lapierre, D. L. Mendrick, W Fiers, R. Rothlein, and T. A. Springer. 1986. Overlapping patterns of activation of human endothelial cells by interleukin 1, tumor necrosis factor, and immune interferon. J. Immunol. 137:1893-1896.

35. Kawasaki, K., E. Yaoita, T. Yamamoto, T. Tamatani, M. Miyasaka, and I. Kihara. 1993. Antibodies against intercellular adhesion molecule-1 and lymphocyte function-associated antigen- 1 prevent glomerular injury in rat experimental crescentic glomerulonephritis. J. Immunol. 150:1074-1083.

36. Eisenberg, S. P., R. C. Thompson, and G. N. Cox. 1989. An interleukin-1 inhibitor (IL-1i) blocks IL-1 induced adhesion of neutrophils to endothelial cells. Cytokine. i:90(a). (Abstr.)

37. Mulligan, M. S., K. J. Johnson, R. F. Todd III, T. B. Issekutz, M. Miyasaka, T. Tamatani, C. W. Smith, D. C. Anderson, and P. A. Ward. 1993. Requirements for leukocyte adhesion molecules in nephrotoxic nephritis. J. Clin. Invest. 91:577-587.

38. Arene, W. P., H. G. Welgus, R. C. Thompson, and S. P. Eisenberg. 1990. Biologic properties of recombinant human monocyte-derived interleukin 1 receptor antagonist. J. Clin. Invest. 85:1694-1697.

39. Charo, I. F., C. Yuen, H. D. Perez, and I. M. Goldstein. 1986. Chemotactic peptides modulate adherence of human polymorphonuclear leukocytes to monolayers of cultured endothelial cells. J. Immunol. 136:3412-3419.

40. McIntyre, T. M., G. A. Zimmerman, and S. M. Prescott. 1986. Leukotrienes $\mathrm{C}_{4}$ and $\mathrm{D}_{4}$ stimulate human endothelial cells to synthesize platelet-activating factor and bind neutrophils. Proc. Natl. Acad. Sci. USA. 83:2204-2208.

41. Gimbrone, M. A., Jr., A. F. Brock, and A. I. Schafer. 1984. Leukotriene $B_{4}$ stimulates polymorphonuclear leukocyte adhesion to cultured vascular endothelial cells. J. Clin. Invest. 74:1552-1555.

42. Hoover, R. L., M. J. Karnovsky, K. F. Austen, E. J. Corey, and R. A. Lewis. 1984. Leukotriene $B_{4}$ action on endothelium mediates augmented neutrophil/endothelial adhesion. Proc. Natl. Acad. Sci. USA. 81:2191-2193.

43. Alexander, H. R., G. M. Doherty, C. M. Buresh, D. J. Venzon, and J. A. Norton. 1991. A recombinant human receptor antagonist to interleukin 1 improves survival after lethal endotoxemia in mice. J. Exp. Med. 173:1029-1032.

44. Gamble, J. R., J. M. Harlan, S. J. Klebanoff, and M. A. Vadas. 1985. Stimulation of the adherence of neutrophils to umbilical vein endothelium by human recombinant tumor necrosis factor. Proc. Natl. Acad. Sci. USA. 82:86678671.

45. Lo, S. K., P. A. Detmers, S. M. Levin, and S. D. Wright. 1989. Transient adhesion of neutrophils to endothelium. J. Exp. Med. 169:1779-1793.

46. Luscinskas, F. W., M. I. Cybulsky, J.-M. Kiely, C. S. Peckins, V. M. Davis, and M. A. Gimbrone, Jr. 1991. Cytokine-activated human endothelial monolayers support enhanced neutrophil transmigration via a mechanism involving both endothelial-leukocyte adhesion molecule-1 and intercellular adhesion molecule-1. J. Immunol. 146:1617-1625.

47. Staunton, D. E., M. L. Dustin, and T. A. Springer. 1989. Functional cloning of ICAM-2, a cell adhesion ligand for LFA-1 homologous to ICAM-1. Nature (Lond.). 339:61-64.

48. Hattori, R., K. K. Hamilton, R. P. McEver, and P. J. Sims. 1989. Complement proteins $\mathrm{C} 5 \mathrm{~b}-9$ induce secretion of high molecular weight multimers of endothelial von Willebrand factor and translocation of granule membrane protein GMP-140 to the cell surface. J. Biol. Chem. 264:9053-9060.

49. Hattori, R., K. K. Hamilton, R. D. Fugate, R. P. McEver, and P. J. Sims. 1989. Stimulated secretion of endothelial von Willebrand factor is accompanied by rapid redistribution to the cell surface of the intracellular granule membrane protein GMP-140. J. Biol. Chem. 264:7768-7771.

50. Geng, J.-G., M. P. Bevilacqua, K. L. Moore, T. M. McIntyre, S. M. Prescott, J. M. Kim, G. A. Bliss, G. A. Zimmerman, and R. P. McEver. 1990 Rapid neutrophil adhesion to activated endothelium mediated by GMP-140. Nature (Lond.). 343:757-760. 